\title{
Association analysis of IL1A and IL1B variants in alopecia areata
}

\author{
RACHID TAZI-AHNINI*+†, ANDREW J. G. McDONAGH + ANGELA COX†, \\ ANDREW G. MESSENGER $\$$, JAMES E. R. BRITTON $\$$, SIMON J. WARD $\dagger$, \\ CLAES O. BÅVIK†, GORDON W. DUFF† \& MICHAEL J. CORK† \\ $\dagger$ Biomedical Genetics Project, Division of Genomic Medicine and $\ddagger$ Department of Dermatology, \\ University of Sheffield, Royal Hallamshire Hospital, Sheffield S10 2JF, U.K.
}

\begin{abstract}
Alopecia areata is an inflammatory hair loss disease with a major genetic component. The disease is characterized by focal inflammatory lesions with perifollicular T-cell infiltrates, reflecting the role of local cytokine production in the development of patchy hair loss. IL- $1 \alpha$ and IL- $1 \beta$ are important inhibitors of hair growth in vitro. Their effect is opposed by the interleukin-1 receptor antagonist, IL-1ra. Genes of the IL-1 cluster are candidate genes in the pathogenesis of alopecia areata. To investigate the role of the IL-1 system in alopecia areata we examined three biallelic polymorphisms within the IL-1 gene cluster $(I L I A+4845, I L 1 B+3954$ and $I L 1 B-511)$ in 165 patients and a large number of matched controls $(n=1150)$. There was no significant association of $I L I B-511$ or $I L 1 B+3954$ genotypes with the overall dataset, or with disease severity or age at onset, in contrast with a previous report. The results suggested the possibility of an association with $I L 1 A+4845$ in the overall dataset [OR 1.39 (95\% CI 1.00, 1.93)] although this was not statistically significant. This was due mainly to the contribution from mild cases of alopecia areata [OR $1.48(0.96,2.29)]$, suggesting that IL-1 $\alpha$ may have a particular role in the pathogenesis of this subgroup.
\end{abstract}

Keywords: alopecia areata, HLA, ILIA, IL1B, interleukin-1, polymorphism.

\section{Introduction}

Alopecia areata is characterized by patchy hair loss with perifollicular and intrafollicular T-cell infiltration (Kalish et al., 1992; McDonagh \& Messenger, 1996). The association of alopecia areata with autoimmunity, including thyroid disorders, pernicious anaemia and vitiligo, is well established (Muller \& Winkelmann, 1963; Cunliffe et al., 1968) and alopecia areata itself is conventionally regarded as an autoimmune disease.

There are no reliable population-based data on the prevalence of alopecia areata in the UK but the lifetime risk of disease is thought to be about $1.7 \%$ in the USA with similar incidence in males and females (Safavi et al., 1995). Up to $40 \%$ of individuals with alopecia areata have a positive family history of the disease (Anderson, 1950; van der Steen et al., 1992) and twin studies (Cole \& Herzlinger, 1984; Scerri \& Pace, 1992) have confirmed that there is a genetic component to the disorder. Several investigators have shown an association between alopecia areata and particular HLA class I alleles including $A 28, B 12, B 13, B 18, B 27$ and $C w 3$

*Correspondence. E-mail: r.taziahnini@sheffield.ac.uk
(Kianto et al., 1977; Hacham-Zadeh et al., 1981; Orecchia et al., 1987; Price \& Colombe, 1996); but HLA Class II associations including $D R 4, D R 11, D P w 4$, $D Q w 3, D Q w 7$ and $D Q w 8$ are considered more important (Frentz et al., 1986; Odum et al., 1990; Duvic et al., 1991). A high relative risk of disease for HLA DR5 $(\mathrm{RR}=3.14, P<0.01)$ was found in patients with severe disease and early age at onset (Price \& Colombe, 1996) and the importance of HLA genes has been confirmed in the only family study reported to date (de Andrade et al., 1999). However, the HLA contribution alone cannot explain the entire genetic basis of alopecia areata, and we have found evidence to suggest the presence of another alopecia areata locus on chromosome 21 (Tazi-Ahnini et al., 2000). Interaction between $H L A$ and other loci is probably required to produce the disease phenotype, as shown for systemic lupus erythematosus (Tjernström et al., 1999).

Interleukin-1 is a highly pro-inflammatory cytokine that promotes recruitment of T-lymphocytes, neutrophils and macrophages to inflamed tissues (Dinarello, 1996). IL- $1 \alpha$, IL- $1 \beta$ and TNF- $\alpha$ are also known to have an inhibitory effect on hair growth in vitro (Harmon \& Nevins, 1993; Philpott et al., 1996). Inhibitory doses of 
these three cytokines have similar effects on the morphology of cultured explant hair follicles resulting in a dystrophic anagen pattern, characterized by condensation of the dermal papilla with disruption and abnormal keratinization of the pericortical cells of the hair matrix. These features are similar to the follicular pathology of alopecia areata (MacDonald-Hull et al., 1991) and the genes for these cytokines are therefore candidate genes in alopecia areata. The IL-1 system consists of at least two agonist molecules, IL- $1 \alpha$ and IL-1 $\beta$, and a structurally related receptor antagonist molecule, IL-1ra. IL-1ra binds to type 1 IL-1 receptors but does not transduce a signal, and therefore acts as a potent anti-inflammatory molecule (Dinarello, 1996).

The $I L 1 A, I L I B$ and $I L 1 R N$ (IL-1 receptor antagonist) genes are clustered within a $430-\mathrm{kb}$ interval on chromosome 2q13 (Nicklin et al., 1994). ILIRN variants are associated with the severity of several inflammatory/ autoimmune diseases, including ulcerative colitis (Mansfield et al., 1994), lichen sclerosus (Clay et al., 1994), psoriasis (Tarlow et al., 1997), myasthenia gravis (Huang et al., 1998), multiple sclerosis (Schrijver et al., 1999) and rheumatoid disease (Cox et al., 1999). We previously reported an association between the rare allele of the $I L I R N$ VNTR and alopecia universalis, the severest form of alopecia areata (Tarlow et al., 1994). This has been confirmed in a recent study in which we showed a strong association with severity of alopecia areata using further markers within the $I L 1 R N$ gene as well as the new ILIRN analogue, ILILI (Tazi-Ahnini et al., in press). In the present study, we have tested alopecia areata for association with three different markers within the IL-1 cluster. Genotypes for the marker $I L 1 B+3954$ are known to influence production of IL-1 $\beta$ (Pociot et al., 1992). We chose the IL1A+4845 polymorphism because it has $100 \%$ linkage disequilibrium with IL1A-889 (Cox et al., 1998), which has also been shown to influence IL-1 $\beta$ production (Hulkkonen et al., 2000). There is strong linkage disequilibrium between $I L I A+4845$ and $I L 1 B+3954$. Weak linkage disequilibrium exists between $I L 1 B-511$ and these two markers (Cox et al., 1998).

\section{Materials and methods}

\section{Patients and clinical assessment}

One-hundred and sixty-five patients with alopecia areata were recruited from dermatology clinics in Sheffield, UK (aged $46.8 \pm 15.4$ years, female:male ratio 1.98). DNA from healthy controls was obtained from 1150 consecutive sample donations to the Trent Blood Transfusion Service, Sheffield; aged $43.9 \pm 11.9$ years, female:male ratio 1.03. Controls were ethnically matched to the disease population (Caucasian, northern European).

The alopecia areata patients entered into this project were managed by three consultant dermatologists (MJC, $\mathrm{AMcD}$ and $\mathrm{AGM}$ ) and had been followed up for 1-6 years. The clinical diagnosis of alopecia areata was based on the presence of initially patchy alopecia with exclamation mark hairs and exclusion of other causes of alopecia (Messenger \& Simpson, 1997). Detailed clinical information was obtained from each patient, including age at onset, family history of alopecia areata, type of disease (patchy alopecia, alopecia totalis and alopecia universalis), concomitant autoimmune diseases and atopy (Table 1). The clinical information was updated at follow-up visits.

\section{DNA analysis}

Genomic DNA was extracted from whole blood according to standard protocols and stored at $100 \mathrm{ng} / \mu \mathrm{L}$. Three single-nucleotide polymorphisms (SNPs) in the IL-1 cluster IL1A $(+4845)$, ILIB $(+3954), I L 1 B(-511)$, were analysed. $25 \mu \mathrm{L}$ PCR reactions comprised $8 \%$ glycerol, $200 \mu \mathrm{M}$ each dATP, dGTP and dCTP, $400 \mu \mathrm{M}$ dUTP, $1.25 \mathrm{U}$ AmplitaqGold (Perkin-Elmer, USA), $1.25 \mathrm{U}$ Uracil-N-Glycosylase (Perkin-Elmer, USA), $5 \mathrm{~mm} \mathrm{MgCl}_{2}$ and $500-900 \mathrm{~nm}$ each primer. Allelic discrimination at these loci was performed using a $5^{\prime}$ nuclease assay (TaqMan allelic discrimination test). This is based on $5^{\prime}$ nuclease activity of Taq polymerase and the detection by fluorescence-resonance energy transfer (FRET) of the cleavage of two probes designed to hybridize to either allele during PCR. Double fluorescent probes were provided by ABI-PE (Forster City, CA; Warrington, UK). Probe and primer sequences, and cycling conditions are detailed in Table 2. Probes were labelled with carboxyfluorescein (FAM) and carboxy $-4,7,2^{\prime}, 7^{\prime}$-tetrachlorofluorescein (TET) fluorescent dyes at the $5^{\prime}$ end, and the quencher carboxytetramethylrhodamine (TAMRA) at the $3^{\prime}$ terminus. Concentrations

Table 1 Clinical characteristics of the patient group

\begin{tabular}{lr}
\hline Clinical type & $n$ \\
\hline Patchy alopecia areata & 92 \\
Alopecia totalis & 26 \\
Alopecia universalis & 40 \\
Ophiasiform alopecia areata & 3 \\
Diffuse alopecia areata & 4 \\
Associated autoimmune disease & \\
$\quad$ Thyroid diseases & 15 \\
Vitiligo & 3 \\
Psoriasis & 1 \\
\hline
\end{tabular}

(c) The Genetics Society of Great Britain, Heredity, 87, 215-219. 
Table 2 Probes and PCR conditions used for genotyping IL1A (+4845), ILIB $(+3954), \operatorname{ILIB}(-511)$

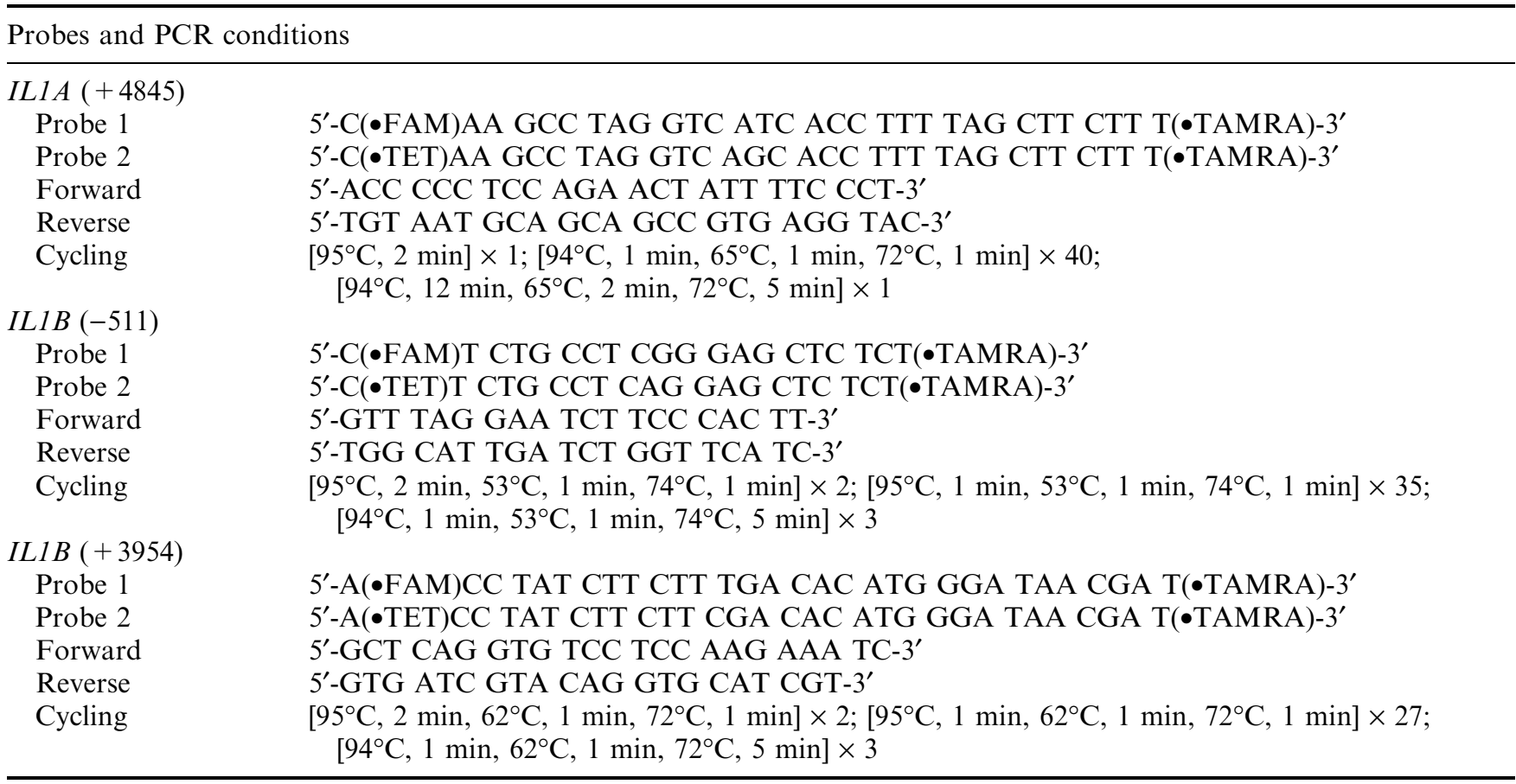

Table 3 Allelic distribution of the three polymorphisms in the IL-1 cluster: ILIA $(+4845), I L 1 B(+3954), I L 1 B(-511)$ in patients and controls. $P$-values are shown uncorrected for the number of tests performed

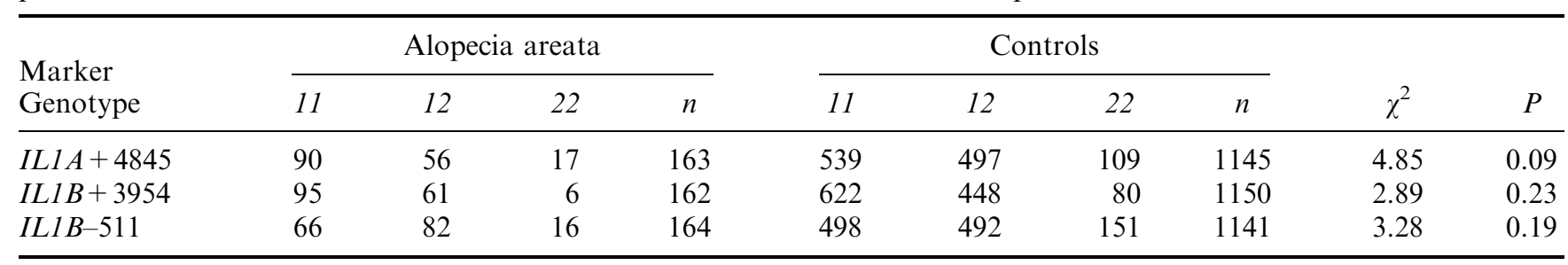

of FAM and TET probes ranged between 20 and $50 \mathrm{nM}$ and 50-350 nM, respectively, depending on the probes used. Plates were scanned in an LS50-B or a PE7200 fluorimeter (ABI/Perkin-Elmer).

In keeping with standard nomenclature, we denoted the common allele ' 1 ' and the rarer allele ' 2 ' for each polymorphic site. Homozygosity is indicated by 1,1 or 2,2 and heterozygosity by 1,2 .

\section{Statistical analysis}

Genotype distributions in cases and controls were compared using $\chi^{2}$-tests on $2 \times 3$ contingency tables. Odds ratios were calculated by combining 1,2 and 2,2 genotypes against 1,1 in $2 \times 2$ tables in the overall dataset and in disease subgroups according to severity.

(c) The Genetics Society of Great Britain, Heredity, 87, 215-219.

\section{Results}

Having checked that there was no significant deviation from the Hardy-Weinberg equilibrium for any of the markers examined $(I L I A+4845, \quad I L 1 B+3954$ and $I L 1 B-511)$ in patients or controls, we examined genotypic distributions of the three markers in alopecia areata patients compared to healthy controls (Table 3). There was no significant difference in the allelic distribution of the $I L I B+3954$ and $I L 1 B-511$ polymorphisms between patients and controls. However, there was suggestive but nonsignificant evidence of association with $I L 1 A+4845$ (Table 3). We then divided the patients and controls into two groups by genotype $(1,1$ vs. $1,2 / 2,2)$. There was borderline association between the ILIA+4845 polymorphism and disease in the overall dataset [OR $1.39(1.00,1.93)]$. 
Subgroup analysis by disease severity suggested that this association was due mainly to the contribution of cases of mild disease (patchy AA) [OR 1.48 (0.96, 2.29)], an apparently weaker association being noted in severe disease (alopecia totalis/universalis) [OR 1.12 $(0.69,1.82)]$.

\section{Discussion}

In the present investigation, we have shown that there is a possible association between alopecia areata and a polymorphism of ILIA $(+4845)$. The effect of this polymorphism may be more pronounced in the milder (patchy) forms of the disease. This is the opposite pattern to our previous findings with $I L I R N$ in which we showed that homozygosity for the rare allele was associated with a greatly increased risk of severe disease (Tarlow et al., 1994). Our current observations add to the evidence suggesting genetic heterogeneity in alopecia areata and the need for larger studies with analysis of well-defined clinical subgroups of disease is emphasized.

We found no association with either of the $I L 1 B+3954$ polymorphisms studied in the overall dataset or in disease severity subgroups. This contrasts with the work of (Galbraith et al., 1999) who reported a weak association with the same marker. However, the power of the Galbraith study was low, around $41 \%$, whereas our study had approximately $90 \%$ power to detect such an effect. It is also possible that the contrasting results may reflect different clinical characteristics in the two patient populations. On the other hand, the main finding in that study was that $I L 1 B$ co-operates with immunoglobulin $\kappa$ light chain genotypes to increase susceptibility to alopecia areata. Other investigators have reported associations with polymorphisms of $I L 1 B$ in a range of inflammatory disorders including inflammatory bowel disease (Stokkers et al., 1998; Nemetz et al., 1999) and insulin-dependent diabetes mellitus (Pociot et al., 1992; Loughrey et al., 1998).

Recently, in our study of the $M X 1$ gene on chromosome 21q22.3 in alopecia areata (Tazi-Ahnini et al., 2000) we showed a significant association of this gene with patchy disease. The role of IL-1 cluster polymorphisms as well as $M X 1$ variants and HLA genotypes in the pathogenesis of alopecia areata requires further examination in large numbers of patients and especially in family studies.

\section{Acknowledgements}

Financial support for this work was provided by the British Skin Foundation and the Sheffield Dermatology Research Fund.

\section{References}

ANDERSON, I. 1950. Alopecia areata: clinical study. Br. Med. J., ii, $1250-1252$.

ClAY, F. E., CORK, M. J., TARLOW, J. K., BLAKEMORE, A. I. ET $A L$. 1994. Interleukin 1 receptor antagonist gene polymorphism association with lichen sclerosus. Hum. Genet., 94, 407-410.

COLE, G. W. AND HERZLINGER, D. 1984. Alopecia universalis in identical twins. Int. J. Dermatol., 23, 283.

COX, A., CAMP, N. J., NICKLIN, M. J. H., DI GIOVINE, F. S. ET $A L$. 1998. An analysis of linkage disequilibrium in the interleukin-1 gene cluster, using a novel grouping method for multiallelic markers. Am. J. Hum. Genet., 62, 1180-1188.

COX, A., CAMP, N. J., CANNINGS, C., DI GIOVINE, F. S. ET AL. 1999. Combined sib-TDT and TDT provide evidence for linkage of the interleukin-1 gene cluster to erosive rheumatoid arthritis. Hum. Mol. Genet., 8, 1707-1713.

CUNLIFFE, W. J., HALL, R., NEWELL, D. J. AND STEVENSON, C. J. 1968. Vitiligo, thyroid disease and autoimmunity. Br. J. Dermatol., 80, 135-139.

DE ANDRADE, M., JACKOW, C. M., DAHM, N., HORDINSKY, M. ET AL. 1999. Alopecia areata in families: association with the HLA locus. J. Invest. Dermatol. Symp. Proc., 4, 220-223.

DINARELlo, C. A. 1996. Biologic basis for interleukin-1 in disease. Blood, 87, 2095-2147.

DUVIC, M., HORDINSKY, M. K., FIEDLER, V.C., O'BRIEN, W. R. ET AL. 1991. HLA-D locus associations in alopecia areata. DRw52a may confer disease resistance. Arch. Dermatol., 127, 64-68.

FRENTZ, G., THOMSEN, K., JAKOBSEN, B. K. AND SVEJGAARD, A. 1986. HLA-DR4 in alopecia areata. J. Am. Acad. Dermatol., 14, 129-130.

GAlbraith, G. M., PAlesch, Y., GORE, E. A. AND PANDEY, J. P. 1999. Contribution of interleukin-1 beta and KM loci to alopecia areata. Hum. Hered., 49, 85-89.

HACHAM-ZADEH, S., BRAUTBAR, C., COHEN, C. A. AND COHEN, T. 1981. HLA and alopecia areata in Jerusalem. Tissue Antigens, 18, 71-74.

HARMON, C. S. AND NEVINS, T. D. 1993. IL-1 alpha inhibits human hair follicle growth and hair fiber production in whole organ cultures. Lymph Cyt. Res., 12, 197-203.

HUANG, D., PIRSKANEN, R., HJELMSTROM, P. AND LEFVERT, A. K. 1998. Polymorphisms in IL-1 $\beta$ and IL-1 receptor antagonist genes are associated with myasthenia gravis. J. Neuroimmunol., 81, 76-81.

HULKKONEN, J., LAIPPALA, P. AND HURNE, M. 2000. A rare allele combination of the interleukin-1 gene complex is associated with high interleukin-1 beta plasma levels in healthy individuals. Eur. Cytokine Network, 11, 251-255.

KALISH, S. R., JOHNSON, K. L. AND HORDINSKY, M. K. 1992. Alopecia areata: autoreactive $\mathrm{T}$ cells are variably enriched in scalp lesions relative to peripheral blood. Arch. Dermatol., 128, 1072-1077.

KIANTO, U., REUNALA, T., KARVONEN, J., LASSUS, A. ET $A L$. 1977. HLA-B12 in alopecia areata. Arch. Dermatol., 113, 1716-1719.

LOUGHREY, B. V., MAXWEll, A. P., FOGARTY, D. G., MIDDLETON, D. ET $A L$. 1998. An interleukin 1B allele, which correlates 
with a high secretor phenotype, is associated with diabetic nephropathy. Cytokine, 10, 984-988.

MACDONALD-HULl, S., NUTBROWN, M., PEPALL, L., THORNTON, M. J. ET $A L$. 1991. Immunohistologic and ultrastructural comparison of the dermal papilla hair follicle bulb from active and normal areas of alopecia areata. J. Invest. Dermatol., 96, 673-681.

MANSFIELD, J. C., HOLDEN, H., TARLOW, J. K., DI GIOVINE, F. S. ET $A L$. 1994. Novel genetic association between ulcerative colitis and the anti-inflammatory cytokine interleukin-1 receptor antagonist. Gastroenterology, 106, 637-642.

MCDONAGH, A. J. G. AND MESSENGER, A. G. 1996. The pathogenesis of alopecia areata. Dermatol. Clin., 14, 661-670.

MESSENGER, A. G. AND SIMPSON, N. B. 1997. Alopecia areata. In: Dawber, R. (ed.) Diseases of the Hair and Scalp, pp. 338369. Blackwell, Oxford.

MUlleR, S. A. AND WinKelmanN, R. K. 1963. Alopecia areata: an evaluation of 736 patients. Arch. Dermatol., 88, 290-297.

NeMETZ, A., NOSTI-ESCANILla, M. P., MOLNAR, T., KOPE, A. ET AL. 1999. IL1B gene polymorphisms influence the course and severity of inflammatory bowel disease. Immunogenetics, $\mathbf{4 9}$, 527-531.

NICKLIN, M. J. H., WEITH, A. AND DUFF, G. W. 1994. A. physical map of the region encompassing the human interleukin- $1 \alpha$, interleukin-1 $\beta$, and interleukin-1 receptor antagonist genes. Genomics, 19, 382-384.

ODUM, N., MORLING, J., GEORGSEN, J., JAKOBSEN, B. K. ET AL. 1990. HLA-DP antigens in patients with alopecia areata. Tissue Antigens, 35, 114-117.

ORECChiA, G., Belvedere, M. C., MARTINetTI, M., CAPElli, E. ET $A L$. 1987. Human leukocyte antigen region involvement in the genetic predisposition to alopecia areata. Dermatologica, 175, 10-14.

PHILPOTT, M. P., SANDERS, D. A., BOWEN, J. AND KEALEY, T. 1996. Effect of interleukins, colony-stimulating factor and tumour necrosis factor on human hair follicle growth in vitro: a possible role for interleukin-1 and tumour necrosis factor- $\alpha$ in alopecia areata. Br. J. Dermatol., 135, 942-948.

POCIOT, F., MÖlVIG, J., WOGENSEN, L., WORSAAE, H. ET AL. 1992. A TaqI polymorphism in the human interleukin-1 beta (IL-1 $\beta$ ) gene correlates with IL-1 $\beta$ secretion in vitro. Eur. J. Clin. Invest., 22, 396-402.
PRICE, V. H. AND COLOMBe, B. W. 1996. Heritable factors distinguish two types of alopecia areata. Dermatol. Clin., 14, 679-689.

SAFAVI, K. H., MULLER, S. A., SUMAN, V. J., MOSHELL, A. N. ET $A L$. 1995. Incidence of alopecia areata in Olmsted County, Minnesota, 1975 through 1989. Mayo Clin. Proc., 70, 628-633.

SCERRI, L. AND PACE, L. J. 1992. Identical twins with identical alopecia areata. J. Am. Acad. Dermatol., 27, 766-767.

SCHRIJVER, H. M., CRUSIUS, J. B., UITDEHAAG, B. M., GARCIA GONZALEZ, M. A. ET AL. 1999. Association of interleukin-1 $\beta$ and interleukin-1 receptor antagonist genes with disease severity in MS. Neurology, 52, 595-599.

STOKKERS, P. C., VAN AKEN, B. E., BASOSKI, N., REITSMA, P. H. $E T A L$. 1998. Five genetic markers in the interleukin 1 family in relation to inflammatory bowel disease. Gut, 43, 33-39.

TARlOW, J. K., ClAY, F. E., CORK, M. J., BLAKEMORE, A. I. ET AL. 1994. Severity of alopecia areata is associated with a polymorphism in the interleukin-1 receptor antagonist gene. J. Invest. Dermatol., 103, 387-390.

TARLOW, J. K., CORK, M. J., CLAY, F. E., SCHMITT-EGENOLF, M. ET AL. 1997. Association between interleukin-1 receptor antagonist (IL-1ra) gene polymorphism and early and lateonset psoriasis. Br. J. Dermatol., 136, 147-148.

TAZI-AHNINI, R., DI GIOVINE, F. S., MCDONAGH, A. J. G., MESSENGER, A. G. ET AL. 2000. Structure and polymorphism of the human gene for the interferon-induced $\mathrm{p} 78$ protein (MX1): evidence of association with alopecia areata in the Down syndrome region. Hum. Genet., 106, 639-645.

TAZI-AHNiNI, R., COX, A., MCDONAGH, A. J. G., NICKLIN, M. J. H. ET AL. 2001. Genetic analysis of the interleukin-1 receptor antagonist and its homologue IL-1L1 in alopecia areata: strong severity association and possible gene interaction. Eur. J. Immunogenet., in press.

TJERnSTRÖM, F., HELlMER, G., NIVED, O., TRUDSSON, L. ET AL. 1999. Synergetic effect between interleukin-1 receptor antagonist allele (IL1RN*2) and MHC class II (DR17,DQ2) in determining susceptibility to systemic lupus erythematosus. Lupus, 8, 103-108.

VAN DER STEEN, P., TRAUPE, H., HAPPle, R., BOEZEMAN, J. ET $A L$. 1992. The genetic risk for alopecia areata in first degree relatives of severely affected patients. An estimate. Acta Dermatol. Venereol. (Stockholm), 72, 373-375. 